\title{
Globalization of the Mind: Canadian Elites and the Restructuring of Legal Fields
}

Harry W. Arthurs

Osgoode Hall Law School of York University, harthurs@osgoode.yorku.ca

\section{Source Publication:}

Canadian Journal of Law and Society/Revue Canadienne Droit et Société. Volume 12, Special Issue 2 (1997), p. 219-246.

Follow this and additional works at: https://digitalcommons.osgoode.yorku.ca/scholarly_works (c) (i) $(9)$

This work is licensed under a Creative Commons Attribution-Noncommercial-No Derivative Works 4.0 License.

\section{Recommended Citation}

Arthurs, Harry W. "Globalization of the Mind: Canadian Elites and the Restructuring of Legal Fields." Le Pluralisme juridique/Legal Pluralism. Spec. issue of Canadian Journal of Law and Society 12.2 (1997): 219-246.

This Article is brought to you for free and open access by the Faculty Scholarship at Osgoode Digital Commons. It has been accepted for inclusion in Articles \& Book Chapters by an authorized administrator of Osgoode Digital Commons. 


\title{
Globalization of the Mind: Canadian Elites and the Restructuring of Legal Fields
}

\author{
H. W. Arthurs* \\ Osgoode Hall Law School \\ York University
}

\begin{abstract}
Globalization is not simply a matter of transnational trade, and of the state, non-state and supra-state legal regimes which facilitate, regulate or resist it; it also involves transnational social, cultural, intellectual and ideological forces. These forces play upon strategically located knowledgebased elites which play an important role in restructuring the legal fields by which public and public and private institutions are constituted. Canada's experience of globalization-unique because of proximity to the United Stateshas been both exemplified and, in part, shaped by the fate of its knowledgebased elites, including the business community (especially that part of it involved directly or indirectly with transnational corporations), academics and intellectuals, lawyers, artists and other cultural figures, and individuals involved in politics and public administration. Because of the effects of this "globalization of the mind" upon the institutions which all of these elites inhabit, state and non-state legal fields associated with them have been transformed.
\end{abstract}

Résumé - La globalisation ne touche pas que les échanges commerciaux transnationaux ou les régimes juridiques étatiques, non étatiques et supra étatiques visant à encourager, à réglementer ou empêcher ces échanges; la globalisation envisage les mouvements transnationaux d'échanges culturels, sociaux, intellectuels et idéologiques. Ces mouvements exercent une influence, bien subconsciente, sur les élites pensantes et influentes ayant une voix importante dans la restructuration du droit qui à son tour modèle l'opinion publique et les institutions étatiques et privées. L'expérience canadienne de la globalisation-unique en son genre en raison de la proximité des États-Unis-a aussi bien servi d'exemple qu'elle calque, en partie, son destin sur celui de l'élite pensante, y compris celle du monde des affaires (particulièrement les membres de cette élite qui oeuvrent directement ou indirectement auprès des sociétés transnationales) et du monde universitaire et intellectuel, les juristes,

* I would like to thank Robert Kreklewich, Kelly Gallagher-Mackay, Tamara Barclay and Troy Ungerman for their research assistance, and the Canadian Institute for Advanced Research and the Social Sciences and Humanities Research Council of Canada for their financial assistance. An earlier version of this paper was delivered at the Annual Meeting of the Law and Society Association, Glasgow in July 1996. 
les artistes et autres personnages du monde culturel, ainsi que les membres de la branche politique et de l'administration publique. En raison de ce phénomène de "globalisation de la pensée» observé au sein des institutions occupées par ces élites, les professions juridiques étatiques et non étatiques liées de près ou de loin à ces institutions ont subi une transformation.

\section{Introduction}

Legal pluralism received its contemporary impetus-if not its initial intellectual inspiration-from anthropological studies which showed pre-modern precapitalist societies to be rich in legal orders even in the absence of conventional state structures. ${ }^{1}$ An important strand within this line of research in legal pluralism was the investigation of encounters between indigenous legal orders and the forces of modernity, capitalism and state law as these were projected by powerful colonial or metropolitan institutions. ${ }^{2}$ Nonetheless, the focus of legal pluralist scholarship remained the arcane or the archaic; it was not thought to have much to do with modern industrial states. Then legal pluralism began to impinge on the consciousness of sociolegal scholars more generally as the result of studies which identified the power and complexity of normative systems which developed "in the shadow" of state law, ${ }^{3}$ or in semi-autonomous social fields characterized by indifference to or deviation from state law. ${ }^{4}$ This was a considerable expansion of the domain of legal pluralism: it was now understood to encompass also the obscure and the illicit. Then studies of modern commercial relationships, government bureaucracies, workplaces and run-ofthe-mill disputing began to reveal that legal pluralism was characteristic not merely of the arcane or archaic, nor even the obscure or illicit, that it is rather a defining feature of the everyday life of capitalist economies, modern societies and organized states. ${ }^{5}$ And most recently, the important work of Santos and

1. Early contributors include B. Malinowski, Crime and Custom in a Savage Society (Paterson: Littlefield, Adams, 1926); L. Pospisil, The Anthropology of Law: A Comparative Theory of Law (New York: Harper \& Row, 1970); M. Hooker, Legal Pluralism: An Introduction to Colonial and Neo-Colonial Laws (Oxford: Oxford University Press, 1975).

2. For a sophisticated reading of the literature, see P. Fitzpatrick, "Law, Plurality and Underdevelopment" in D. Sugarman, ed., Legality, Jdeology and the State (London \& New York: Academic, 1983) 159.

3. See e.g. M. Galanter, "Justice in Many Rooms: Courts, Private Order and Indigenous Law" (1981) 19 Journal of Legal Pluralism 17.

4. S. F. Moore, "Law and Social Change: The Semi-autonomous Social Field as an Appropriate Subject of Study" (1973) 7 Law \& Society Rev. 719.

5. See, for a general theoretical introduction, J. Griffiths, "What is Legal Pluralism?" (1986) 24 Journal of Legal Pluralism 1, and for a comprehensive review of the 
others has used the insights of legal pluralism to help us to understand the complex and ubiquitous phenomenon we call globalization as a proliferation of contending normative orders.

The legal field in contemporary societies and in the world is a far more complex and richer landscape than has been assumed by liberal political theory; ... such a legal field is a constellation of different legalities (and illegalities) operating in local, national and transnational time-spaces; ... and the way law's potential evolves, whether towards regulation or emancipation, has nothing to do with the autonomy or self-reflexiveness of law, but rather with the political mobilization of competing social forces. ${ }^{6}$

At one level, globalization describes a series of related corporate initiatives: the development of transnational product and capital markets, transnational production and procurement strategies, transnational information flows and management structures. By virtue of being corporate, these initiatives remind us that normative regimes are the creation not only of states but also of non-state institutions; by virtue of being transnational, they remind us that the capacity of states to coerce and control is constrained not only by social and economic and cultural factors-an insight from the literature of legal pluralism-but by geography as well.

Nonetheless, globalization cannot exist apart from the state; indeed, it might be said to depend crucially upon a series of governmental responses to globalizing corporate initiatives. The state is needed to create transnational normative regimes-such as the WTO-which facilitate global trade, to revise national regimes-such as tariffs and intellectual property laws-which might impede it, and to suppress non-state regimes-such as labour agreements and social practices-whose dominant actors might wish to deflect the consequences of globalization or to "misappropriate" its gains. And non-state agencies also help to shape transnational legal regimes: corporations, banks, markets, law firms and consulting firms, arbitrators, sectoral and regional trade, professional and financial organizations, as well as transnational social movements and human rights agencies are creating a new lex mercatoria ${ }^{7}$ and, one would like to

literature on the "old" and "new" legal pluralisms, S. Merry, "Legal Pluralism" (1988) 22 Law \& Society Rev. 869.

6. B. de Sousa Santos, Toward a New Common Sense: Law, Science and Politics in the Paradigmatic Transition (New York: Routledge, 1995) at 111.

7. For a review of the European literature, see H.-J. Mertens, "Lex Mercatoria: A Self-applying System Beyond National Law?" in G. Teubner, ed., Global Law without the State: Studies in Modern Law and Policy (Aldershot: Dartmouth, 1997) 31. But see also Y. Dezalay \& B. Garth, "Merchants of Law as Moral 
believe, a new jus humanitatis. ${ }^{8}$ In short, globalization takes place both within and across the boundaries defined by state, supra-state and non-state regimes of legal ordering.

However, there is more to globalization than transnational corporate activity, the state-sponsored and transnational regimes which reinforce it, and the non-state regimes which regulate or resist it. If the WTO were to dissolve, if protectionism or autarky should again assert their ancient charms, if transnational corporations were all to settle into the congenial domesticity of social markets, this would not mean the end of globalization. We would still be deeply implicated in a global system driven not only by trade and economics, but also by transnational social and cultural, intellectual and ideological forceswhat I refer to as "globalization of the mind." These forces play with particular force upon national, knowledge-based elites whose embrace of, or aversion to, globalization of the mind is an important determinant (but not the only one) of the extent to which national polities and private businesses become implicated in transnational economic systems.

Given the overall logic of examining globalization as a site of research on critical legal pluralism, why concern ourselves with this particular manifestation, globalization of the mind, and the elites it most affects? There are three reasons. First, we have to remind ourselves that globalization is not the ineluctable fate of nations; it is wrought by-and works upon-human intelligence, desire and belief. Second, the fate of elites offers a certain perverse perspective on globalization. While the adverse effects of globalization are rightly perceived to fall on vulnerable communities in peripheral countries, such effects are also beginning to be more widely distributed. In trade-sensitive countries such as Canada, even knowledge-based elites-supposedly amongst the prime beneficiaries of globalization-may be at risk. As I will argue, globalization of the mind threatens to destroy their comparative advantage-local knowledge and influence. It does so in part by reshaping their mentalities, and the ways in which they function professionally, comprehend their country and deal with the world, but also in part by altering their material circumstances, as globalization forces the restructuring of national economic, cultural and governmental regimes in which they work. And third, related knowledge-based elites-policy communities or epistemic communities ${ }^{9}$-play an important role in shaping

Entrepreneurs: Constructing International Justice from the Competition for Transnational Business Disputes" (1995) 29:1 Law \& Society Review 27.

8. de Sousa Santos, supra note 6 at $365 \mathrm{ff}$.

9. See e.g. M. Atkinson \& W. Coleman, "Policy Networks, Policy Communities and the Problems of Governance" (1992) 5:2 Governance 155; P. Haas, "Introduction: Epistemic Communities and International Policy Coordination” (1992) 46:1 International Organization 1. 
those economic, cultural and governmental regimes. Whether they do so in their own interest ${ }^{10}$ or as agents of dominant forces associated with the changing world economic system ${ }^{11}$ is for current purposes somewhat beside the point. In either case, globalization of the mind facilitates the restructuring of state and non-state legal fields.

For many of Canada's knowledge-based elites, optimism about globalization is an article of faith; pessimism is, if not a heresy, at least a sin. Pessimist and sinner that I am, I must perform the customary penance: mortification by caveat. To whit: my pessimism is qualified; Canada is not only a victim of globalization, but in some ways also a beneficiary; globalization of the mind, the subject of this essay, can be separated analytically but not empirically from the other powerful forces of the New Economy; and despite globalization and its adverse effects, Canada and its elites will likely remain relatively privileged compared to most other countries and social groups. Nonetheless, despite these caveats, I hope that by identifying recent changes in Canada's knowledge-based elites under conditions of globalization, I will be able to bring into focus one important source of the transformations occurring in the broader Canadian society, economy and polity and in the legal fields by which these are constituted.

\section{The Canadian Context}

Certain features of Canada's social and economic reality help to explain why the transformation of elite attitudes, values and understandings might in turn result in the restructuring of legal fields. Canada's economy is export-dependent to an unusual degree and the United States is by far its largest market. ${ }^{12}$ But it is not

10. In general, see P. Bourdieu, "The Force of Law: Toward a Sociology of the Juridical Field" (1987) 38 Hastings L.J. 805; Y. Dezalay \& D. Sugarman, Professional Competition and Professional Power: Lawyers, Accountants and the Social Construction of Markets (London: Routledge, 1995); B. Bercusson, "Economic Policy: State and Private Ordering" in T. Daintith, ed., Law as an Instrument of Economic Policy: Comparative and Critical Approaches (Berlin: Walter de Gruyter, 1988) 359; T. Wilhelmsson, "Legal Integration as Disintegration of National Law" in H. Petersen \& H. Zahle, eds., Legal Polycentricity: Consequences of Pluralism in Law (Aldershot: Dartmouth, 1995) 127; S. Gill, "Globalization, Market Civilization, and Disciplinary Neo-Liberalism" (1995) 24:3 Millennium Journal of International Studies 399.

11. de Sousa Santos, supra note 6.

12. Exports account for 40 to $45 \%$ of the Canadian GDP. According to the Historical Statistical Supplement (1995/96) Canadian Economic Observer. Amongst the G-7 countries, only Germany trades more than Canada as a percentage of its gross domestic product. See S. Blank, "The Emerging Architecture of North America" 
just export-dependent. Many key sectors of Canada's economy have long been dominated by foreign, principally American, firms ${ }^{13}$ and indeed much of its international trade flows between these foreign firms and their Canadian subsidiaries. ${ }^{14}$ Thus, barring a dramatic and unanticipated change in patterns of trade, Canada's prosperity largely depends upon the capacity of our business elites-domestic and imported-to stimulate American investment in Canada and demand for Canadian goods and services in the United States. Moreover, the United States figures no less importantly in our political calculus than in our economy. For example, Canada's capacity to sustain even a modest version of the welfare state depends upon the skill of our civil servants in reaping and spending tax revenue, much of which is generated by American investment. Even in debates over national unity, both sovereigntists and federalists seem to regard privileged access to American trade and investment as a trump card, to be played in an endgame of Quebec secession.

Further, given the relatively late, precarious, and still-contested development of a Canadian national identity, and of institutions which promulgate and express it, our elites have often manifested a degree of "cultural cringe," a susceptibility to cultural, intellectual, technological and scientific influences from abroad, and especially from the United States. Or, more accurately, Canadian artists and scholars have been profoundly ambivalent over whether they should define themselves as not-Americans or as candidate-

(Miami: University of Miami, 1993). Over $80 \%$ of Canada's merchandise exports go to the United States; See S. Weintraub, "Current State of U.S.: Canada Economic Relations" (1994) 24:4 American Review of Canadian Studies 473.

13. U.S. direct investment in Canada was about $63 \%$ of all direct foreign investment as of 1991 , which represented a decline from over $85 \% 40$ years earlier. However, it was still almost three times greater than investment from the European Union, the next largest source. J. Niosi, "Foreign Direct Investment in Canada" in Industry Canada, Multinationals in North America (Calgary: University of Calgary Press, 1994) 367. Overall, American-owned companies control $11.4 \%$ of the assets of Canadian companies, but $20 \%$ of the operating revenues; comparable figures for firms owned in all other foreign countries are $10 \%$ of both corporate assets and operating revenues. In other words, American-owned firms are strategically located in growing areas of the economy. I. Fellegi, Foreign Control in the Canadian Economy 1995, vol. 1 (Ottawa: Statistics Canada, 1997).

14. One study estimates that between 60 to $65 \%$ of cross-border trade by foreignowned subsidiaries is with their parent firms. S. Krajewski, Intrafirm Trade and the New North American Business Dynamic (Ottawa: Conference Board of Canada, 1992). Another study suggests that about $70 \%$ of Canada's merchandise exports to the United States are not at arm's length: about $40 \%$ are intrafirm transfers, and another $30 \%$ result from licensing and interfirm understandings. See Weintraub, supra note 12. 
Americans, whether they should struggle towards or away from the centre of American cultural and intellectual life.

Finally, as a thinly populated, heterogenous, regionalised ex-colony, Canada's version of the Keynesian welfare state developed in tandem with its search for national identity and through the modality of an expanding national government. ${ }^{15}$ However, as Canada's welfare state has come under pressure from globalization, neo-conservative ideologies (largely emanating from the United States), Quebec nationalism and other centrifugal influences, its political elites and governments-the authors and instruments of the welfare state-are experiencing extreme stress. ${ }^{16}$

These facts help to explain why globalization has a somewhat different meaning for Canada than for, say, Sweden or Korea or Brazil. For many Canadians, globalization, regional integration within NAFTA, and continentalism are all more or less synonymous; all imply closer integration of Canada into the economic structures, idiosyncratic ideology and powerful culture of American capitalism. ${ }^{17}$ Integration, moreover, seems likely to unwind the elite consensus which has been a feature of post-war Canadian politics ${ }^{18}$ and therefore of the institutional structures and normative regimes which express it.

This conclusion does not require a romantic view of the politics of elite accommodation: Canada's elites were neither meritocratically nor democratically constituted, nor have they been equally influential or powerful in the post-war period, ${ }^{19}$ nor has accommodation amongst them been explicit or unidirectional. ${ }^{20}$

15. See e.g. J. Jenson, " 'Different' But Not 'Exceptional': Canada's Permeable Fordism" (1989) 26:1 Canadian Review of Sociology and Anthropology 69; J. Jenson, "Mapping, Naming and Remembering: Globalization at the End of the Twentieth Century" (1991) 2:1 Review of International Political Economy 96.

16. C. Tuohy, Policy and Politics in Canada (Philadelphia: Temple University Press, 1992) at c. 8 cites two dramatic events-the advent of free trade and the rejection of the Meech Lake and Charlottetown Accords-as evidence of the dysfunctionality of Canada's system of elite accommodation.

17. See W. Hutton, The State We're In (London: Jonathan Cape, 1995) at 275ff; B. Stallings \& W. Streeck, "Capitalisms in Conflict? The United States, Europe and Japan in the Post-Cold War World" in B. Stallings, ed., Global Change, Regional Response (Cambridge: Cambridge University Press, 1995) 67.

18. J. Porter, The Vertical Mosaic (Toronto: University of Toronto Press, 1965); R. Presthus, Elite Accommodation in Canadian Politics (Toronto: Macmillan, 1973).

19. See e.g. S. Bashevkin, "Does Public Opinion Matter? The Adoption of Federal Royal Commission and Task Force Recommendations on the National Question: 1951-1987" (1988) 31:1 Canadian Public Administration 390.

20. W. Clement, The Canadian Corporate Elite (Toronto: McLelland \& Stewart, 1975); A. P. Williams \& L. Panitch, ed., The Canadian State (Toronto: University of Toronto Press, 1977); A. P. Williams, Elite Conflict and Accommodation in the 
But if there is some reason to discount nostalgia for Canada's "golden age" of elite accommodation, there is rather less reason to understate the possible longterm effects of globalization of the mind. Globalization-ratified but not initiated by our accession to a continental free trade agreement - has undermined the position of many elite producers of wealth, ideas, culture, law and public policies and altered their relationship to each other and to the state. The possible consequences include increased insecurity for each of these elites, defection from the previous consensus, and debilitating intra- and inter-group conflict. This essay will provide a brief narrative describing these developments, and conclude with some speculations about how they may bring about the restructuring of legal fields.

\section{Changes in the Structure of the Transnational Firm: The Hollowing Out of Corporate Canada ${ }^{21}$}

As has been persuasively argued, the transnational firm is itself a "transnational law making community,"22 a "pluralistic legal order." ${ }^{23}$ Changes in the structure and dynamic of these firms are likely to affect not only the internal legal field of the firm itself, but as well adjacent legal fields-other firms, communities, states-whose fortunes are closely intertwined with those of transnationals. Such effects are particularly likely to occur in countries such as Canada in which transnationals play such a leading role.

Canada's manufacturing sector, in particular, has been dominated by the branch plants and supplier networks of transnational-primarily Americancompanies which, in most cases, located in Canada in order to gain entry to the Canadian market. ${ }^{24}$ True, absent any serious legal obstacles or tax penalties, ${ }^{25}$

Welfare State: Patterns of Contact Between Canadian State, Business and Labour Leaders (Toronto: Institute for Social Research, York University, 1987).

21. This section is based on a study-in-progress of changes between 1985 and 1995 in the corporate structures of the 115 largest Canadian subsidiaries of foreign-owned transnational corporations. The study is intended for publication in R. Buchanan, J. Jenson \& B. de Sousa Santos, eds., Navigating Through Globalizations: The Challenge to Institutions [tentative title; forthcoming 1998].

22. P. Muchlinski, "'Global Bukowina' Examined: Viewing the Multinational Enterprise as a Transnational Law-making Community" in Teubner, supra note 7, 79.

23. J.-P. Robé, "Multinational Enterprises: The Constitution of a Pluralistic Legal Order" in Teubner, ibid., 45.

24. See supra notes 12 to 14 .

25. Non-resident (i.e. non-Canadian) companies may carry on business in Canada simply by registering in a Canadian jurisdiction. See e.g. Extra-Provincial 
some of these transnational firms elected to do business in Canada from their foreign base or with only a small Canadian sales office, but without a Canadian corporate charter, directors or officers. But more often they established subsidiaries which operated as "mini-replicas" of the parent firm, produced a relatively full line of goods for Canadian customers, raised capital in Canadian markets, and were run by Canadian-based directors and managers who enjoyed a degree of autonomy from their foreign parent. ${ }^{26}$

Changes in the organization and technology of production, in transport and communications technology, and in the global character of capital markets now make it possible and profitable for transnational companies to alter these arrangements. Instead of producing a wide range of goods, Canadian subsidiaries are given world or regional mandates, for a short list of products or for a limited range of components, in order to achieve economies of scale. Indeed, some companies have abandoned production in Canada altogether, and reduced their operations in Canada to the point where they now do little more than distribute goods made elsewhere. In either case, corporate functions once performed in Canada no longer are. The result may ultimately be a declining demand in Canada for "advanced producer services" - the high-value-added, communications-intensive services which sophisticated global corporations either produce for themselves or contract to buy from others. ${ }^{27}$

For example, capital can be raised outside of Canada - even from Canadian investors-by banks and brokerage houses and other providers of related services operating in New York, London or Tokyo. ${ }^{28}$ Advertising need not be,

Corporations Act, R.S.O. 1990, c. E.27. However, a company which fails to register is "not capable of maintaining any action or proceeding ... in respect of any contract made by it ..." (s. 21(1).) A pending amendment appears to place "branch operations" of non-resident companies in the same position for tax purposes as subsidiaries which are incorporated in Canada. See Income Tax Act, R.S.C. 1985 (5th Supp.) c. 1 as am., s. 219(1), (1.1).

26. M. Kriger \& P. Rich, "Strategic Governance: Why and How MNCs are Using Boards of Directors in Foreign Subsidiaries" (1987) 22:4 Colorado Journal of World Business 39.

27. See generally, on this development, P. Daniels \& F. Moulaert, eds., The Changing Geography of Advanced Producer Services (London \& New York: Belhaven 1991); UNCTAD, World Investment Report 1994: Transnational Corporations, Employment and the Workplace (New York: United Nations, 1994).

28. While international investment is increasingly volatile and increasingly dominated by large institutional lenders, the Toronto Stock Exchange has so far held its own as an attractive site for global investors. D. Gould, "Big Money Goes Global" [Toronto] Globe and Mail (1 August 1995) B9. However, there remains a real risk that further consolidation of global markets in a few favoured sites may ultimately prejudice the position of Toronto and other Canadian markets. 
and often is not, produced in Canada. It can now be transmitted directly across the border from the United States, or produced there and exported to Canada for dissemination through Canadian media. ${ }^{29}$ Research and development (R \& D) are generally concentrated at the foreign headquarters of multinationals, rather than performed within the Canadian subsidiary, a fact which may help to explain why Canada spends less on R \& D than many other advanced economies. ${ }^{30}$ The pattern with regard to advanced producer services is varied-law, for example, is generally sourced locally - but within a general trend to globalization, there seems to be some tendency toward concentration of most highly specialized and firm-specific services in proximity to corporate headquarters. ${ }^{31}$ Indeed, even when a substantial range of operations has been maintained in Canada, foreign head office control has generally become more intrusive and extensive, encompassing even locally-contracted providers of advanced producer services.

The results of this change are not likely to be neutral, nor are they intended to be. The new logic of global corporate integration increases the pressure for aggressive action by subsidiary companies to achieve efficiency in their designated area of activity. ${ }^{32}$ Canadian managers, generally perceived as cautious and polite, are enjoined to adapt to the new climate or run the risk of being displaced by Americans, even in Canadian-owned firms. ${ }^{33}$ Corporate functions once performed in Canada are assigned to absentee managers, service providers and professionals. These new arrangements increase the likelihood that deliberately, or by inadvertence, corporate decisions will be made without

29. This would appear to be part of a world-wide trend. See P. Mitchell \& J. Bright, "Multinational Headquarters Control of UK Subsidiaries' Advertising Decisions" (1995) 14 International Journal of Advertising 183.

30. For an interesting linkage between the percentage of GDP spent by various countries on R \& D and their influence on scientific research based on a scientific citation index, see R. May, "The Scientific Wealth of Nations" (1997) 275 Science 793. Canada ranks sixth amongst the G7 nations in the former category and seventh world-wide in the latter. Canada is outranked in both indicators by several small countries: Sweden, Switzerland, the Netherlands and Denmark.

31. See generally Y. Aharoni, Coalitions and Competition: The Globalization of Professional Business Services (London: Routledge, 1993).

32. Industry Canada, Business Development Initiatives of Multinational Subsidiaries in Canada (Paper No. 2) by J. Birkinshaw (Ottawa: Industry Canada, Occasional Paper Number 2, 1995) and "Taking the Initiative" (1995) 59:4 Business Quarterly 97; P. Bristol, "Three Years Later: Canadian Subsidiaries Fight for a Share of the New North American Market" (1992) 52:1 Food in Canada 13; B. Milner, "Free Trade Wave Rocks the Canadian Boat" (1994) 7 International Business 79.

33. M. Drohan, "What Makes a Canadian Manager?" [Toronto] Globe and Mail Report on Business (25 February 1997) B18; G. MacDonald, "Why U.S. Imports Get the Big Jobs" (Torontol Globe and Mail (1 May 1997) B14. 
particular regard for Canadian laws, ${ }^{34}$ conventions of business behaviour or the sensibilities of local communities or governments. ${ }^{35}$ They are also likely to reshape the non-state regimes which regulate social and economic relations within a firm, or between it and its workers, customers and suppliers. ${ }^{36}$

These outcomes are made more likely by the erosion of the formal channels through which Canadian perspectives were once transmitted to the transnational parent company: the senior management and board of directors of the Canadian subsidiary. Whereas many large, publicly-traded Canadian companies were in fact controlled by a dominant shareholder, their parent U.S. firm, they are now being reintegrated into the parent firm as wholly-owned, privately-held subsidiaries. As a result, their Canadian boards of directors survive, if at all, only in vestigial form; their managements are accountable not to Canadian directors but directly to the foreign head office or to an operating sub-unit based abroad, likely in the United States; and neither directors or managers are in a position to exert much influence, if any, on the central direction of the transnational firm. ${ }^{37}$

With the influence of their Canadian shareholders, directors and highpowered Canadian executives eliminated or diminished, these "hollowed out" Canadian subsidiaries are likely to be less willing or able to argue as effectively as they once did against plant closures or for extended product mandates in Canada, or for a larger Canadian share of global R \& D activities.

This is not to deny that, even without the advocacy of a strong board and management, the Canadian subsidiaries may, at a given moment and for good, competitive reasons, attract investment and generate employment. Indeed, in recent years, American and other foreign investment in Canada and Canadian exports to the United States and elsewhere have both been growing. ${ }^{38}$ This success may reflect the productivity of Canadian workers, special advantages of

34. M. Starr, "Who's the Boss? The Globalization of U.S. Employment Law" (1996) 51 Business Lawyer 635.

35. For recent journalistic discussion, see S. Blank, "U.S. Impressions of the Quebec Election" (1994) 3:2 Canada Watch 13; J. Gillies \& D. Morra, "Stakeholders and Shareholders in a Global World" (1996) 17:10 Policy Options 32; L. Medcalf, "Is Canadian Advertising on the Line?" Marketing Magazine (I July 1996) 12; M. O'Neil, "Inching Toward Hegemony" (1996) Canadian Computer Reseller 14.

36. J.-G. Belley, "Contrat et citoyenneté: La Politique d'achat regional d'une entreprise multinationale" (1993) 34:3 Cahiers de droit 1063; J.-G. Belley, "Contract, Legal Pluralism, Global Economy and Human Development" (Toronto: Canadian Institute for Advanced Research, 1994) [unpublished].

37. Of course, much will depend upon the outlook and strategy of the parent company. See R. Kustin \& R. Jones, "The Influence of Corporate Headquarters on Leadership Styles in Japanese and U.S. Subsidiary Companies" (1995) 16:5 Leadership and Organization Development Journal 11.

38. L. Laliberté, "Globalisation and Canada's International Investment Position" (1993)

3:1 Canadian Economic Observer 31; Niosi, supra note 13. 
geography enjoyed by the Canadian operation, hidden subsidies (such as publicly-funded health care, which reduces employers' payroll costs) or the effects of neo-conservative initiatives to deregulate the workplace and the environment, to reduce tax burdens and to create a more "business-friendly" policy environment-strategies which are themselves arguably the manifestation of globalization of the mind. ${ }^{39}$

Ironically, however, Canadian executives of transnational subsidiaries may in the future be less influential in the adoption of such policies. Given their diminished mandates and their increasingly precarious local tenure, they are less likely to provide leadership in Canadian business circles ${ }^{40}$ or, more generally, to participate actively in the Canadian policy community. ${ }^{41}$ This, of course, by no mean implies that their ultimate employers-foreign-based transnationals-will be less successful in shaping the course of Canadian public policy by means of direct negotiation, lobbying or overt and implicit threats to disinvest: only that their local executives may become less influential actors and less significant agents.

Trade theorists may argue-the evidence is mixed, the point is controversial-that Canada derives net economic benefits from these new arrangements in which Canadian subsidiaries produce more goods within narrower mandates while performing fewer of the advanced producer services usually associated with head office activity. ${ }^{42}$ And they are very likely to contend that there is not much Canada can do to alter the mix: it is notoriously difficult to regulate advanced business and producer services, even within highly

39. R. Grinspun \& R. Kreklewich, "Consolidating Neo-Liberal Reforms: 'Free Trade' as a Conditioning Framework" (1994) 43 Studies in Political Economy 33.

40. However, the present situation may be no more than an extrapolation of a longer trend. Over 20 years ago, a study described the CEOs of foreign-owned companies-with specified exceptions-as "surrogates, colonial administrators responsible to invisible men in a foreign land, transitory creations of offshore head offices who exercise little real clout and despite their very real collective authority figure only marginally in any audit of personal business power on the Canadian scene." P. Newman, The Canadian Establishment, vol. 1 (Toronto: Seal, 1977) at 201-02.

41. Ironically, this might have the effect of diminishing their influence within the Business Council on National Issues, a lobby group on which transnationals were heavily represented, and one of the prime movers in the successful effort to persuade the Canadian government to adopt free trade policies. See R. O'Brien, "North American Integration and International Relations Theory" (1995) 28:4 Canadian Journal of Political Science 693.

42. J. Harrington, "Implications of the Canada-United States Free Trade Agreement for Regional Provision of Producer Services" (1989) 65:4 Journal of Economic Geography. 314; J. François, "Trade in Producer Services and Returns due to Specialization under Monopolistic Competition" (1990) 23:1 Canadian Journal of Economics 109. 
prescriptive trade regimes..$^{43}$ However, this does not mean that we can ignore the largest consequences of this new dispensation: its possibly profound effects on Canadian urban life and the cosmopolitan activities which are its hallmark.

Saskia Sassen has noted that "[ $t]$ he territorial dispersal of economic activities, of which globalization is one form, contributes to the growth of centralized functions and operations" concentrated in so-called "global cities" and in "regional nodes ... at smaller geographic scales and lower levels of complexity than global cities." "Major cities," she says, "are centres for the servicing and financing of international trade and investment, and headquarters operations. And in this sense they are strategic production sites for today's leading economic sectors." The emergence of global cities and regional nodes, she concludes, has contributed to a "new geography of centrality and marginality" which occurs within and amongst cities. ${ }^{44}$ This, I would propose, is one manifestation of globalization of the mind.

What does this analysis imply for Canada? Regional centres such as Toronto, ${ }^{45}$ Calgary and Vancouver ${ }^{46}$ have also been important and growing markets for advanced producer services. However, if present trends continue, if the head offices of Canadian subsidiaries disappear or are confined to a narrow range of functions, if Canadian operations are increasingly managed by U.S.centred regional business units, we can expect some deterioration of the quality of Canadian metropolitan life. This phenomenon is already visible in many American regional centres and in Montreal, whose density of head offices has declined markedly in recent years. ${ }^{47}$ Furthermore, the diminished presence of head offices and/or regional offices generates a reverse multiplier effect, whose consequences will be most marked for those lower on the "food chain." For example, carriage trade service industries such as restaurants and clothing stores,

43. K. Nicolaidis, "Mutual Recognition, Regulatory Competition and the Globalization of Professional Services" in Aharoni, supra note 31.

44. S. Sassen, Cities in a World Economy (Thousand Oaks: Pine Forge, 1994) at 119. See also P. Daniels, Service Industries in the World Economy (Oxford: Blackwell, 1993) c. 4 and 5.

45. Sassen, supra note 44 at $82-85$ specifically examines the growth of the Toronto financial district, though her analysis does not take into account the deep recession which began in 1989, nor the restructuring of the Canadian economy under globalization.

46. T. Hutton \& D. Ley, "Location, Linkages and Labour: The Downtown Complex of Corporate Offices in a Medium Size City, Vancouver, British Columbia" (1987) 63 Economic Geography 126; W. Michalak \& K. Fairbairn, "The Producer Service Complex of Edmonton: The Role and Organization of Producer Service Firms in a Peripheral City" (1993) 24 Environment and Planning 761.

47. However, there is some suggestion that "Quebec's home-grown multinationals" may have begun to fill the void. K. Yakabuski, "Quebec Unshaken by Exodus" [Toronto] Globe and Mail (17 March 1997) B1. 
the ensemble of professionals who finance and build head offices, and the beneficiaries of corporate philanthropy ${ }^{48}$ may all suffer.

Once again, the consequences of these changes are likely to be reflected in both public and private normative systems. In the "new geography of centrality and marginality," deregulation of land use, tax incentives and investment in public infrastructure are common strategies used by cities to renew or reinforce their centrality and attract or retain prestigious and strategic head offices and regional centres; police measures are used to suppress or cosmeticize the incipient effects of marginalization; and both types of measures have private sector parallels-flexibility in land use, incentivized rents, provision of "smart buildings" and high tech support systems, and on the coercive side, the deployment of vast private security forces.

Of course, it is not inevitable that Canada's metropolitan centres should experience such convulsive consequences. Even if foreign multinationals persist in "hollowing out" their subsidiaries to the prejudice of their Canadian subsidiaries and the communities they inhabit, it is possible that Canadian-based companies, especially transnationals, could more than fill the void: this is apparently the gamble which governments take when they embark on a policy of promoting globalization and regional economic integration. However, relatively few such Canadian firms exist ${ }^{49}$; some of those which did have been absorbed into larger U.S. and other foreign-based companies ${ }^{50}$; and others which have survived and flourished as Canadian transnationals appear to be gradually shifting their operations, management and capital abroad. ${ }^{51}$ A new generation of Canadian companies may ultimately achieve sufficient size to provide a domestic substitute for the restructured foreign transnationals, but they are not yet visible, nor is the nature of the comparative advantage they will require if

48. V. Murray, Improving Corporate Donations: New Strategies for Grantmakers and Grantseekers (San Francisco: Jossey-Bass, 1991).

49. UNCTAD, supra note 27 at c. 1, ranks three Canadian-based transnational companies as 34th, 65th and 74th amongst the largest 100 such companies; one of these is listed as "high growth," one as "no growth" and one as "decline." In all, the survey identifies 1396 Canadian-based transnationals amongst a world total of 37,530. The UNCTAD survey does not indicate whether some of these Canadianbased transnationals are themselves subsidiaries of foreign-based transnationals. (Financial and investment firms are not included.)

50. The pharmaceutical industry is a good example. See M. Anderson, "Collaborative Integration in the Canadian Pharmaceutical Industry" (1993) 25 Environment and Planning 1815 at $1818-19$.

51. See e.g. J. Fleming, "Conquering Canadians" [Toronto] Globe and Mail (15 December 1989) P30; J. Lewington, "Firms Going Continental Under Free Trade Pact" [Toronto] Globe and Mail (2 April 1990) B1; K. Valaskis, "Era of the Nomad Corporation" [Toronto] Globe and Mail (20 November 1991) Al8. 
they are to achieve the necessary growth, diversity, specialization and staying power.

To sum up: changes in the structure of authority within transnationals almost certainly imply a change in their internal normative systems, likely with greater dissonance between such systems and those in adjacent legal fields, public and private. And more generally, if current trends in the restructuring of these companies continue, if centralization of advanced producer services in a limited number of global cities proceeds apace, Canada confronts at least the possibility of marginalization by degrees. It is in this latter sense that globalization of the mind operates to the disadvantage particularly of strategically-important knowledge-based Canadian business and industrial elites.

The "hollowing out" of corporate Canada may in this way implicate other sectors which interact with or depend upon business-which is to say just about all elements of Canadian society. Canada would then have a much-reduced capacity to sustain a robust welfare state, a vibrant cultural and intellectual community, a progressive system of law and public administration and, indeed, the habits of elite accommodation which helped to bring about all of these in the first place.

\section{Academic and Intellectual Life}

No less important than the closer integration of their Canadian subsidiaries into the decision-making matrix of transnational companies has been the integration of Canadian academics and intellectuals into the global, and especially the continental, intellectual community and labour market. This integration has taken three distinct forms: the domination of the academic labour market by American and American-trained recruits, the recruitment of Canadian scholars into a continental epistemic community, and the adoption of public and institutional policies in the higher education sector which reflect American sociocultural and political values.

Over the protests of concerned nationalists, ${ }^{52}$ large numbers of foreign academics were hired during the period of rapid university expansion in the 1960 s. In reaction to the real prospect of a "branch-plant" Canadian higher education sector, immigration controls were introduced to discourage the hiring

52. See e.g. R. Mathews \& J. Steele, The Struggle for Canadian Universities (Toronto: New Press, 1969); T. H. B. Symons \& J. E. Page, To Know Ourselves: Report of the Commission on Canadian Studies (Ottawa: AUCC, 1975). 


\section{of foreign-principally American-academics. ${ }^{53}$ In this they largely succeeded. ${ }^{54}$}

However, attempts to exclude American academics were rather beside the point, since we rightly (and inevitably) maintained open borders so far as foreign ideas and experiences were concerned. In consequence-lacking a mature or self-confident academic culture of its own, ${ }^{55}$ and exposed by reason of its physical, linguistic and cultural proximity to the United States-, Canadian academe and the professions have been considerably influenced by American scholarship. This seems to be especially true in policy disciplines such as sociology, ${ }^{56}$ politics, ${ }^{57}$ economics, ${ }^{58}$ law,,${ }^{59}$ management ${ }^{60}$ and public

53. Employment and Immigration Canada, Employment Manual, s. 17.36 (Foreign Academics).

54. These measures appear to have been largely successful: in 1969-1970, Canadians held $57 \%$ of all university teaching jobs; by $1988-1989$, this had risen to $81 \%$. Statistics Canada, Teachers in Universities (Ottawa: Minister of Industry, Science and Technology, 1992).

55. I do not mean to ignore the teachings of Harold Innis, which are particularly salient in any discussion of the linkages between the domestic and world economies, and between the economy and culture. See D. Drache, ed., Staples, Markets and Cultural Change: Selected Essays by Harold A. Innis (Montreal \& Kingston: McGill-Queens University Press, 1995). However, Innis' views are hardly dominant amongst Canadian academic economists today.

56. See generally S. Brooks \& A.-G. Gagnon, eds., Social Scientists, Policy and the State (New York: Praeger, 1990).

57. See e.g. A. Pross, "Canada in the American Arcade: Is Pluralism a Distorting Mirror?" in L. Douzuniskis, M. Howlett \& D. Laycock, Policy Studies in Canada: The State of the Art (Toronto: University of Toronto Press, 1996) 33.

58. See e.g. P. Huwitt, "Twenty-Five Years of Canadian Economics" (1993) 26:1 Canadian Journal of Economics 1. P. Fortin, "Where We Were. Where We Are: The First Eight CEA Meetings and the Last Four," ibid. at 55, reports a discernible decline in published articles with some Canadian content (46\% to $33 \%$ ) and an increase towards articles which are purely theoretical. As non-academics are more likely to publish articles with Canadian empirical or policy content, amongst academic economists, the decline is even greater.

59. My preliminary analysis of teaching and scholarship in administrative and constitutional law shows that professors with graduate degrees from U.S. institutions constitute an absolute majority (about 53\%) of those teaching in the field in common law schools, and an even larger proportion (about 64\%) of those who have published English language books on either subject. As an interesting sidelight, there is a clear divergence between civil and common law scholars in these politically sensitive fields. U.S. graduate degrees are relatively rare in civil law schools; Canadian and French graduate degrees are equal in number (about $34 \%$ ); and Canadian-trained authors contribute a disproportionate share of publications (about 43\%). Conceivably, this is one source of the divergence in attitudes within legal academe towards the state, federalism, individual and 
administration ${ }^{61}$ where, though often contested, American graduate training, scholarly literature and academic practice remain highly influential.

To be sure, academics and policy professionals have the opportunity and the obligation to rise above their own intellectual formation, to draw on worldwide academic cultures and scientific traditions, and still to be sensitive to the claims of Canadian context and circumstance. However, on the one hand, forces in the academic market place may discourage research on Canada in some disciplines. ${ }^{62}$ On the other, apart from any power derived from their provenance, ideas generated in American universities and think-tanks do appear to influence intellectual and political discourse all over the world. This is true especially in Canada, ${ }^{63}$ where the policy disciplines must respond to a public agenda and public opinion which are directly and heavily influenced by cross-border messages emanating from the American media. Thus, it is not surprising that we often define problems, assume social facts, adopt methodologies, embrace values, and borrow policy prescriptions from the United States, as if the two halves of North America were integrated not just economically but intellectually, politically, socially and culturally. ${ }^{64}$

This is not a phenomenon which began with the most recent wave of globalization, nor is it confined to matters which are immediately relevant to economic integration. In earlier times, the Canadian policy community relied on progressive precedents from the United States to shape our collective bargaining and anti-discrimination legislation, to improve regulation of the environment and the securities market, to enhance consumer protection and occupational health

collective rights etc. as between Quebec and the rest of Canada. This hypothesis gains strength to the extent that common law professors with Canadian graduate degrees training were in many cases taught by professors of an earlier generation who were themselves mostly American-trained..

60. Newman, supra note 40, Appendix C, "The Harvard Business School Clan."

61. See e.g. B. Peters \& D. Savoie, "Reinventing Osborne and Gaebler: Lessons from the Gore Commission" (1994) 37:2 Canadian Public Administration 302.

62. A. Scott, "Does Living in Canada Make One a Canadian Economist?" (1993) 26:1 Canadian Journal of Economics 26 at 37 notes that "over half of Canadian [economics] teachers and researchers were born, bred or trained outside Canada," that a desire to maintain international mobility leads to a de-emphasis on Canadian topics, and that-while some important evidence points the other way- "it is possible that increasing international integration will make academics devote less time to hometown problems and more to the mix of economists' global preoccupations."

63. S. Clarkson, "Economics: The New Hemispheric Fundamentalism" in R. Grinspun \& M. Cameron, The Political Economy of North American Free Trade (Montreal \& Kingston: McGill-Queens University Press, 1993) 61.

64. O'Brien, supra note 41. 
and safety, and of course, to constitutionalize fundamental rights and freedoms. ${ }^{65}$ More recently, academic research and public debate have also begun to address the American neo-conservative agenda, including deregulation, privatization, curtailment of public spending, abandonment of social programs, the defence of gun ownership and "family values" and a crusade against crime, the abuse of social entitlements and illicit immigration. Obviously we have spoken to these issues in our own national and regional idioms, but the technology of social ordering in Canada, no less than that of manufacturing or medicine, is increasingly globalized, which is to say that for Canada, it is largely imported from a single source-the United States. ${ }^{66}$

Finally, and not least, globalization of the mind is manifest in Canada's importation of neo-conservative higher education policies - arriving in this instance not only from the United States but also from Thatcherite Britain via Australia and New Zealand-which are beginning to reshape the institutional as well as the intellectual life of Canadian universities. ${ }^{67}$ Government grants are falling, tuition fees and student indebtedness are rising, private sector research partnerships are being encouraged, the state's monopoly on higher education is being questioned, and new procedures and performance standards are being introduced to ensure greater accountability, productivity and "value-added" in our universities. ${ }^{68}$ These measures may further reduce the capacity, and ultimately the inclination, of Canadian universities to resist globalization in its most importunate-American-manifestation.

These developments within Canada's higher education sector force us to recall that, like corporations, universities are themselves legal fields, sites of pluralistic legal systems which directly govern their students, staff and faculty. And, as in the case of corporations, these developments will also alter the indigenous normativity of adjacent fields, especially policy networks, cultural institutions, the professions, public administration and other sectors with which universities are closely linked.

65. See e.g. C. Bennett, "How States Utilize Foreign Evidence" (1991) 11:2 Journal of Public Policy 31 (freedom of information legislation); G. Hoberg, "Sleeping with the Elephant: The American Influence on Canadian Environmental Regulation" (1991) 11:2 Journal of Public Policy 107; C. Manfredi, "The Use of United States Decisions by the Supreme Court of Canada Under the Charter of Rights and Freedoms" (1990) 23:3 Canadian Journal of Political Science 499.

66. See e.g. D. Schneiderman, "NAFTA's Takings Rule: American Constitutionalism Comes to Canada" (1996) 46 University of Toronto L. J. 499.

67. J. Cutt \& R. Dobell, Public Purse, Public Purpose: Autonomy and Accountability in the Groves of Academe (Halifax: Institute for Research on Public Policy, 1992).

68. See e.g. Report of the Commission of Inquiry on Canadian University Education (Smith Report) (Ottawa: AUCC, 1991); Report of the Task Force on University Accountability (Broadhurst Report) (Toronto: Ontario Ministry of Colleges and Universities, 1993). 


\section{The Legal Profession ${ }^{69}$}

When we turn from public to private institutions of social ordering, the picture looks rather similar. Lawyers play a crucial role in the economy-as intermediaries amongst elites in government, finance and other sectors-and in public policy formation, as the architects of contractual and corporate structures, regulatory regimes, tax strategies and of techniques for circumventing all of these. ${ }^{70}$

Nonetheless, the effects of globalization of the mind are beginning to be felt even by the legal profession, which is usually regarded as a particularly well-entrenched professional elite, protected by the local nature of its knowledge, by statutory monopolies and by its own strong traditions and pervasive influence. The legal profession, however, also happens to be a prime example of an advanced producer service. As such, it is bound to be affected by the "hollowing out" of Canadian subsidiaries, an important source of clients, revenues and influence. Moreover, the effects of corporate restructuring by transnational companies upon the profession will be exacerbated by the simultaneous-and arguably related-retrenchment of the state. Depleted funding for legal aid and deregulation, for example, will also deprive the Canadian bar of important spheres of practice.

In addition to these very real economic concerns, globalization of the mind presents a particular problem for the legal profession. The comparative advantage of Canadian lawyers resides in who they know and what they know, information whose shelf-life is being foreshortened by globalization and continental integration. While access to influential Canadian business and governmental actors is still important for foreign investors, it is somewhat less so to the extent that they need not resort to Canadian capital markets and have less to fear from Canadian regulatory requirements; in certain key areas, international conventions and treaties require that Canadian law and practice be harmonized with regional or global regimes, and American legal ideas and practices-disseminated through professional journals, client encounters and the mass media-generate pressures for convergence between Canadian and American law. All of these developments are transforming the political economy of the Canadian legal profession.

This transformation is evident in certain trends which are "Americanizing" the Canadian legal profession and legal system: the stratification of the profession, the growth of large corporate "law factories," the mass-marketing of

69. See generally H. W. Arthurs \& R. Kreklewich, "Law, Legal Institutions and the Legal Profession in the New Economy" (1996) 34:1 Osgoode Hall L. J. 1.

70. See generally M. Cain, "The Symbol Traders" in M. Cain \& C. Harrington, eds., Lawyers in a Postmodern World: Translation and Transgression (New York: New York University Press, 1994) 15. 
standard legal services, more aggressive competitive practices, the politicization of professional governance, and on the substantive side, in the judicialization of politics under the Charter, the juridification of social movements, and the use of class actions as a regulatory strategy. ${ }^{71}$ While Canadian legal culture and professional practice still retain some distinctive features, as more and more Canadian lawyers learn to think and act like American lawyers, and as more and more of their clients expect them to do so, those distinctions will gradually fade away. And finally, as Canadian subsidiaries of foreign companies are increasingly deprived of autonomy, as their legal strategies are increasingly determined at the head offices of their U.S.-based parent firms, the Americanbased global law firms which advise those parent firms are likely to become as influential in Montreal, Vancouver and Toronto as in Paris, London and Amsterdam. As "trade followed the flag" in the hey-day of European imperialism, so too law will follow trade in the present era of American-led globalization. ${ }^{72}$

\section{Culture}

If law follows trade, culture may even precede it. American films, television, sport and other vehicles of mass culture are, if not ubiquitous, at least sufficiently so to be fairly described as global. What is global as well is the commodification of American culture in the form of an entertainment "industry" "73 built especially upon new and newly reinforced forms of intellectual property. ${ }^{74}$ This presents a problem for all countries and cultures, but again Canada is a special case. ${ }^{75}$ The power, size, technology and proximity of the United States all combine to make Canada's culture-high and lowparticularly vulnerable to integration into that of the United States. Sensitivity to this vulnerability has been a focal point in debates over Canada's cultural policy, negotiations over globalization and, especially, regional economic integration. But Canada's desire for cultural sovereignty has not been easy to vindicate: it

71. H. W. Arthurs, "Legal Practise in Canada in the 21 st Century" (1996) 15 Windsor Yearbook of Access to Justice 202.

72. D. Trubek et al., "Global Restructuring and the Law: Studies of the Internationalization of Legal Fields and the Creation of Transnational Arenas" (1994) 44 Case W. Res. L. Rev. 407.

73. See e.g. J. Van Maanen, "Displacing Disney: Some Notes on the Flow of Culture" (1992) 15:1 Qualitative Society 4. The author (mercifully) omits to mention that Disney Corp. has been hired to market one of the most quintessentially Canadian of all images: that of the R.C.M.P.

74. See R. Davidson, "Intellectual Property" in D. Cameron \& M. Watkins, eds., Canada Under Free Trade (Toronto: James Lorimer, 1993) 214.

75. And within Canada, Quebec is an even more special case. 
clashes directly with the determination of the United States to achieve free trade in cultural goods and services, one of its largest exports. ${ }^{76}$ Thus, attempts to protect Canada's cultural sovereignty have been a source of ongoing conflict between the two countries, despite reassurances which were supposedly provided under the original FTA as well as NAFTA. ${ }^{77}$

It is sometimes argued that the advancement of Canadian culture should not take the form of discrimination against American publications, films or television programs, that subsidization of the arts and publishing and broadcasting is more cost-effective, not to mention more consonant with Canada's legal commitments to free trade. But culture-unlike cars or clothing-is not merely a consumer good: in its many manifestations it expresses the character and values of a nation, which is why culture is so often contested and controversial. That is why even countries with cultures more ancient, assertive and well-financed than Canada's-France for example-have been adamant in their resistance to the invasion of U.S. cultural goods. ${ }^{78}$ Moreover, there is something disingenuous about proposals to use subsidies rather than exclusionary strategies to protect Canadian culture in light of the retrenchment of state funding for the arts, the enfeeblement of the $\mathrm{CBC}$ and other state-supported institutions, and the absence of a strong Canadian tradition of private benefaction.

The other policy option is for Canadian cultural producers to enlarge their markets, to become more aggressive in selling their wares abroad. But this option is also fraught with contradictions. Canada is a small market. Consequently, Canadian producers must penetrate U.S. markets not merely to

76. J. Thompson, "Canada's Quest for Cultural Sovereignty: Protection, Promotion, and Popular Culture" in S. Randall et al., eds., North America without Borders? (Calgary: University of Calgary Press, 1992) 393.

77. P. Kresl, "Your Soul for a Case of Coors?: Canada-U.S. Free Trade and Canadian Culture Policy" in P. Kresl, ed., Seen from the South (Provo: Brigham Young University, 1989) 159; J. Zemans, "'And the Lion Shall Lie Down with the Lamb": U.S.-Canada Cultural Relations in a Free Trade Environment" (Winter 1994) American Review of Canadian Studies 509. (Readers may share my sense of irony at citing on this point two works which appear in U.S. journals.)

78. Disagreement over protection for domestic cultural industries was one of the most difficult issues to resolve during both the NAFTA negotiations and the Uruguay Round of GATT negotiations. See e.g. R. Davies, "Signing Away Canada's Soul: Culture, Identity and the Free Trade Agreement" (1989) 278 Harper's Magazine 43; C. Fuller, "Fade to Black: Culture Under Free Trade" (August 1991) Canadian Forum 5; M. McDonald, "A Futile Struggle to Withstand U.S. Culture" Toronto Star (9 October 1993) C4-C6; J. Rever, "France Faces off with Rambo" [Toronto] Globe and Mail (4 February 1995) C9; D. Fagan, "Will that be Culture-or Cash?" [Toronto] Globe and Mail (29 January 1996) B1-B2; D. Fagan, "U.S. Takes Canada to Trade Court "[Toronto] Globe and Mail (12 March 1996) A1. For a technical analysis, see B. Appleton, Navigating NAFTA (Toronto: Carswell, 1994). 
earn back their costs of production, but to validate their "world-class" credentials by successfully competing in the home market of the leading cultural exporter. Yet, it seems that Canadians generally believe that, in order to compete successfully abroad, they must become less obviously Canadian, more completely assimilated into a homogeneous North American culture. And to compound the difficulty, Canadian artists, performers and athletes, ${ }^{79}$ individually and collectively, suffer from the smallness of the domestic market and its limited facilities, training programs, television markets, competition and rewards.

In any event, whatever the hypothetical merits of such policies, they are not being pursued with any degree of success. The influence of American culture in Canada has become pervasive: it by-passes normal point-of-entry restrictions via the scores of American TV channels available to Canadians; its market dominance and folkloric power is evident in areas as different as fashion and sport, ${ }^{80}$ in patterns of movie and video distribution in Canada, in material disseminated by sound recordings and on the Internet, ${ }^{81}$ in magazines, in book publishing and book selling, ${ }^{82}$ in curatorial practice in galleries and museums. ${ }^{83}$

In its own way, what Canada is experiencing is only a particularly intense illustration of the consequences of globalization. This development is positive insofar as it helps to link Canada to broad developments in world culture. But globalization of the "marketplace of ideas"-the double entendre is intentional-also helps to incorporate us into a North American cultural space which is, at the same time, a market for cultural goods produced for export in the United States.

The implication of all these developments for Canada's cultural elites is rather clear and discouraging. Being distinctively Canadian is not the path to

79. Even "Canada's National Game" is becoming increasingly less Canadian. Two Canadian NHL franchises-Winnipeg and Quebec-have recently been forced by financial pressures to move to the United States; few Canadian teams are advancing into post-season play in the NHL; and few Canadians are ranked amongst its elite players.

80. See B. Kidd, "How Do We Find Our Own Voices in the 'New World Order'? A Commentary on Americanization" (1991) 8 Sociology of Sport Journal 178; J. Harvey \& F. Houle, "Sport, World Economy, Global Culture and New Social Movements" (1994) 11 Sociology of Sport Journal 307.

81. See e.g. P. Audley, "Cultural Industries Policy: Objectives, Formulation, and Evaluation" (1994) 19 Canadian Journal of Communication 317.

82. See e.g. B. Bergman, "Publish and Perish" 107 Maclean's Magazine (17 October 1994) 50.

83. See e.g. J. Stoffman, "U.S. Scholar Will Head AGO" Toronto Star (27 May 1995) A3; J. B. Mays, "Misplaced Cosmopolitanism at the AGO" [Toronto] Globe and Mail (3 June 1995) C 15; S Riley, "Must We Surrender Even our Galleries?" Toronto Star (3 June 1995) J8. 
success; it is a virtual assurance that they will forego the financial and psychic rewards available to elite cultural producers in other countries. Nor does it seem that we are likely to change soon. Even the building blocks of a made-in-Canada policy which might challenge American cultural hegemony are lacking: a conceptual vocabulary, factual information, a sense of direction, institutional structures, and financial resources. ${ }^{84}$

We are now coming to see how globalization of the mind is in the process of dissolving Canada's cultural identity, save for those parts of it-francophone Quebec, aboriginal peoples and the multicultural communities-deemed not to have global salience or commercial potential. Accepting that there are risks of serious abuse in attempting to construct a Canadian volkgeist, it can hardly be denied that the absence of common beliefs, cultural referents, and national symbols vastly complicates attempts to construct a Canadian consensus on normative issues ranging from the constitution to education to immigration to foreign investment and media ownership.

\section{Public Administration ${ }^{85}$}

Canada's political culture is increasingly "globalized" as well. All the forces which once promoted activist government in the national interest are in retreat: the "red Tories," the social democratic and labour movements, the progressive and nationalist wing of the dominant Liberals, Keynesian-minded civil servants and the "chattering classes" in general. True, critique continues; alternative voices are occasionally heard, ${ }^{86}$ but they are not heard loudly. There is little prospect of early recovery: electoral politics are in disrepute; participation in civic activities is in decline, single issue constituencies wage war by poll, petition, fax and lawsuit, and anti-state and anti-tax rhetoric seems all-pervasive. Ironically, even emancipatory movements, such as those seeking to mobilize women, first nations, blacks, gays and greens, borrow inspiration, rhetoric and strategies from their counterparts in the United States, and to that extent-albeit often with good reason and for high motives-contribute to the Americanization of the Canadian polity.

84. See generally R. Lorimer \& N. Duxbury, "Of Culture, the Economy, Cultural Production and Cultural Producers: An Orientation" (1994) 19 Canadian Journal of Communication 259.

85. See H. Arthurs, "Mechanical Arts and Merchandise: Canadian Public Administration in the New Economy" (1997) 42:1 McGill L. J. 29.

86. For several recent social democratic critiques, with proposed strategies to respond to globalization and continental economic integration, see Grinspun \& Cameron, supra note 63. 
All of this is very much in the spirit of an emerging globalquintessentially American-political culture, and it certainly alters the context within which public administration is conducted in Canada.

To sum up a complex and depressing narrative, in Canada at least we are witnessing a dilution of the quality and competence of public administration, a decline in the professionalism and morale of the public service and an erosion of broad democratic accountability. At the same time, tax-averse cost-conscious governments-from neo-conservatives to social democrats-are increasingly abandoning traditional state functions in favour of privatized, marketized or hybrid arrangements, centralizing political control of state functions, reducing local government, public consultation and expert inputs, and introducing tough managerial strategies standards modelled on private sector management practices.

In many respects, then, the travails of the Canadian public service resemble those in other advanced industrialized countries. If they differ in degree or nuance, the explanation probably lies in our proximity to the United States, and our historic affinity to the United Kingdom, two countries which have been leaders in rolling back the state. For present purposes, however, what is important is that we are coming to the end of the mandarinate - the rule of a meritocratic elite in government - and of the moral entrepreneurship of public servants, two traditions reaching back to the early days of the Victorian welfare state, traditions which left their stamp especially on the civil servants who pragmatically built Canada's post-war welfare state and held the federation together.

In terms of the restructuring of legal fields within public administration, many changes are already obvious. To name a few: down-sizing and reduced activism in the public service with consequent reduction of its capacity to penetrate social and economic relationships in the private sector, consolidation of local governments and specialized agencies with consequent loss of their close affinities with the constituencies they govern or regulate, ${ }^{87}$ abolition of policy and research units ${ }^{88}$ with a consequent reduction of internal critique of

87. Most notoriously in Ontario, see City of Toronto Act, S.O. 1997, c. 2 (amalgamating the six constituent municipalities of Metropolitan Toronto); Fewer School Boards Act, S.O. 1997, c. 3 (reducing the number of local school boards, and bringing educational policy and expenditure more closely under control of the provincial Ministry of Education and Training).

88. The Ontario government recently announced that it would eliminate 22-and possibly 34 - of its 50 advisory agencies (including the Law Reform Commission, the Women's Directorate, the Anti-racism Directorate and the Council on University Affairs) in response to the recommendations of its Task Force on Agencies, Boards and Commissions chaired by Robert Wood, Parliamentary Assistant to the Chair of Management Board of Cabinet. According to Hon. David Johnson (Chair of Management Board of Cabinet): "As this government has said 
government policies and, perforce, increased reliance on private sector consultants, and, finally, the acquisition by the Treasury of virtual veto power over policy development in other departments, with consequent promotion of economistic over social values in government policy-making. Parallelling these developments, and equally important, are deregulation, privatization or hybridization of government functions, and the reduction of transfer payments both from the central government to the provinces and from government generally to individuals. The intended, and likely achievable, effect of all of these is to reduce the state's presence and to enlarge the sphere of the "private"-a process which has no conceivable purpose except to bring about changes in the content of the norms which govern our communal life, and in the patterns of personal activity which such norms are meant to induce or compel.

\section{Conclusion: The Transformation of Legal Fields in Canada}

This essay has focussed on how globalization of the mind is affecting the role of Canadian elites in constructing and reconstructing legal fields in the state and non-state spheres. In concluding, it is necessary to reinforce a point made earlier. Elites are not autonomous and omnipotent; they do not construct or deconstruct legal fields at will, without the participation of other actors, in neglect or defiance of culture, history, economics or politics. But elites can, and do to some extent, influence normative regimes as mediators and negotiators amongst divergent interests and tendencies, as articulators and administrators of formal discourse and structures, as observers and interpreters of the informal and the inchoate. For this reason, it is important to understand how globalization of the mind has affected Canadian elites.

Canadian elites are particularly susceptible to this particular form of globalization because of Canada's long history as an importer of ideas and culture, as well as technology and capital. Canada's private sector elites may well be imperilled by the current tendency of transnational corporations to reinforce head office control over their subsidiaries, with resulting knock-on effects for providers of advanced business services, and more generally, for metropolitan areas whose economies are closely tied to the levels and varieties

many times, in an environment of restructuring and cost reduction you've got to find new ways to do business. The same is true for our advisory agencies. Whenever possible, government will seek advice through volunteers and less formal processes. Where formal advisory agencies continue to be used as a method of consultation or advice, government will look for qualified people who are willing to serve on a voluntary business." Ontario , Official Report of Debates (29 May 1996) at 3146. 
of economic activity generated by head offices and regional offices. Further, many Canadian elites are employed by, involved with, or dependent upon state and para-state institutions. To the extent that globalization has helped to disempower the regulatory state, their material circumstances have deteriorated and their very raison d'être has been challenged.

True, not all members of Canada's elites are equally at risk. No doubt, some Canadian artists, business executives, academics and lawyers will be very successful in high-stakes global competition, even while prospects for the rest seem to be deteriorating. However, the result is likely to be intra-elite and interelite disagreement over public policies and institutional practices which are perceived to favour global winners as against local losers, or vice versa. Indeed, elite dissensus has been exacerbated by ideological debates over the relative attractions of markets, communities, and states. Whereas elite accommodation once focussed on how to orchestrate these different modes of social and economic organization-especially, in Canada, through the building of national institutions-today they are portrayed as mutually exclusive, since only markets have a global dimension, while states and communities are geographically bounded.

The argument of this essay--and the burden of the admittedly impressionistic evidence submitted in support-is that the transformation of Canadian elites by globalization has in fact been quite extensive. Given the specific circumstances of Canada, globalization of the mind in particular has contributed to a convergence of ideas, policies and behaviours as between Canadian elites and their counterparts in the United States. Or, more accurately, conventional wisdom and practice in the two countries, in a number of areas, seem to have converged around American models, while distinctive Canadian ways of seeing and doing things appear to be drifting into eclipse. As a consequence, Canadians are increasingly implicated in a common "constellation of different legalities (and illegalities)" 89 with their powerful neighbour. The "legalities" in question include legislation and legal doctrines, political discourse and conventions, technocratic interventions (and noninterventions) by public agencies and officials, norms of corporate and commercial behaviour, programs and strategies of emancipatory and conservative movements, the private governance provided by law firms and consultancies, ways of understanding the world transmitted through scholarship and high culture, and a great congeries of patterned behaviours reinforced by mass education and popular culture.

The limits of this claim must be clearly acknowledged. The "different legalities" we are now experiencing do not derive simply from systemic reflexivity or the self-imposed exertions and derelictions of our own elitesthough the importance of these should not be underestimated. Rather, these new legalities ultimately reflect the logic of America's economic, political and

89. de Sousa Santos, supra note 6. 
cultural hegemony. Ultimately, but not proximately: power is both mobilized and mediated through globalization of the mind. It produces a degree of likemindedness amongst the theoreticians, strategists, advisors and operatives who deploy their intelligence, passion and professional skills in creating powerful ideas, institutions and normative orders which, to some degree, predominate in most countries of the industrialized West, and elsewhere as well. At the same time, however, globalization of the mind engenders a new local dynamic, whose consequences are not easily foreseen, a point which will be addressed below.

Thus, the argument is not that globalization and regional economic integration are unmitigated disasters, that these transformative and traumatic developments can, should or will be reversed. On the contrary, at least for these purposes, it is possible to accept that, for Canada, the net economic effects of globalization may well have been positive. It is disconcerting, however, to reflect on the extent and rapidity with which Canadian policies, laws and practices were brought into line with those of the new global regimes. Particularly striking was the construction of new domestic and transnational institutions-new "constellations of legalities"-intended to ensure that policies which reinforced globalization and regional integration were well nigh irreversible. Examples range from "national treatment" requirements in free trade treaties to conventions governing specific strategic goods, such as intellectual property, to proposals now being pursued in the European Union and in individual states-including Canada-to institutionalize the current financial orthodoxy of limited public expenditure. As each of these is put in place, globalization-a new and controversial premise of Canadian public policybecomes a more and more firmly established organizing principle of both public and private arrangements.

It is true that Canada, like other states, still holds the formal levers of power in its own hands. We still elect parliaments; they still pass laws; the coercive power of the state can in theory be mobilized to enforce those laws and we can still change course. But the formal levers of power are not much use without a directing intelligence, a capacity to perceive where our interests lie and how they might best be defended through subsidies, ownership requirements, tax policies or otherwise. Globalization of the mind has to some extent eroded that intelligence in the case of Canada, or more accurately, it has taught us how to think about those interests, those defensive strategies, in a particular way which is consonant with the views of elites across the global economy. Given its pervasive effects upon so many key sectors of Canadian life, it is difficult to imagine how we might resist globalization or even attempt to modify it in order to preserve some capacity to pursue our self-interest and preserve our identity. This is, of course, pretty much a working definition of globalization of the mind.

Yet, despite all of this, globalization of the mind may also, to coin a phrase, contain the seeds of its own destruction. Partly, this is because, as has been 
noted, globalization is beginning to injure the interests of knowledge-based elites. Such elites generally play a key role in designing, articulating and implementing any complex regime of governance, private or public, national or transnational. Their disaffection would consequently represent a seriouspossibly fatal-obstacle to the continuation of current policies of unregulated globalization. Partly, too, this is because knowledge-based elites are, at some level, committed to questioning prevailing orthodoxies, as Kuhn proposed in his theory of paradigmatic change. For both of these reasons, it would not be wholly surprising if "globalization of the mind," in the end, facilitated the spread of contrapuntal ideas and alternative institutions and normative orders which represented considerable departures from those we are now experiencing.

However, it is one thing to predict the ultimate abatement of globalization and amelioration of its worst effects, quite another to make practical proposals to bring this about. Are such proposals in fact at all realistic for a country like Canada?

Essentially, Canada has four options. The first is the "softest" and the likeliest to be pursued. We might simply accept that we are too small, too weak, too divided internally, to deviate from whatever course the global economic consensus-and regional hegemony - decrees. We would, in this scenario, wait passively for the emergence of a new global consensus, and then adapt it to our specific circumstances. Or, second, we might-if it were somehow possible to mobilize popular support for such measures-serve timely notice that we were resigning from all Faustian bargains such as NAFTA and the GATT and accept the widely-predicted consequences-disinvestment, shrinking tax revenues, disappearing jobs and a declining quality of life. It is improbable that Canada or any other country would knowingly risk such consequences: but it is not impossible. Or, third, we might turn back to the state as the instrument of our collective values and interests, and aggressively exploit whatever margins of independent action remain to us within the existing constraints of free trade and high levels of absentee ownership. This is, in essence, the social democratic option, which was tried in France at the beginning of the 1980s, in Ontario and Quebec, and to some degree in Saskatchewan and British Columbia-in all cases so far with no discernible success.

Finally-in addition or in lieu-, we might attempt to persuade our knowledge-based elites to dilute, resist, subvert, even reverse, globalization of the mind. This is not quite so unlikely a project as it might initially appear. As I have attempted to show, elites themselves are not immune from the adverse effects of globalization, and a more jaundiced view of the process might serve their own interests. Moreover, the privileged position of elites allows them to achieve subtly and by indirection what, in many ways, the state cannot achieve by formal action alone: a new set of attitudes and understandings and, ultimately, new institutions and new legalities. 